DOI: $10.21554 / \mathrm{hrr} .091905$

\title{
PRESENCE OF RISK FACTORS IN PRIMARY SCHOOL STUDENTS AND THE NEED FOR EARLY SOCIAL-PEDAGOGICAL INTERVENTION
}

\author{
Adela Jahić1,a \\ Emina Suljkanović-Djedovićc \\ Lejla Kuralić-Čišića \\ Meliha Bijedića
}

Original scientific paper

${ }^{a}$ Faculty of Education and Rehabilitation, University of Tuzla, Bosnia and Herzegovina

${ }^{b}$ Public institution, Primary School "Klokotnica”, Doboj Istok, Bosnia and Herzegovina

Received: 2019/6/28

Accepted: 2019/9/3

\begin{abstract}
The school is an institution that represents an important link in the social care chain for children and young people, which also involves taking various measures to prevent the occurrence of undesirable behaviors. The aim of the study is to determine the prevalence of risk factors between adolescents with externalized and internalized problems and typically developing adolescents, and to determine in which segment, in the opinion of teachers, early social-pedagogical intervention is most needed. The research sample is made up of 450 students (233 male and 217 female) of the seventh and eighth grades of primary school. The results show that the highest risk factors are present in the group of students with externalized behavioral problems, slightly less in the group with internalized problems, and the least in students without behavioral and emotional problems. When it comes to early social-pedagogical interventions, in the opinion of teachers, they should be comprehensive and implemented by a competent expert.
\end{abstract}

Key words: early social-pedagogical intervention, adolescents, risk factors, school environment.

\section{INTRODUCTION}

As a child grows up, it is increasingly exposed to a variety of environmental factors, which is especially reflected during schooling when the school environment and peers assume the role of the main agent of socialization. The school is an institution that represents an important link in the social care chain for children and young people, which also involves taking various measures to prevent the occurrence of undesir- able behaviors. In a school context, it is possible to develop, implement and monitor in the best possible way a comprehensive support system that respects the needs of all students in the school (Sprague \& Walker, 2000).

The school has great potential in terms of fostering children's development, creating a positive environment, spotting the first signs of risky behavior and responding promptly and appropriately to prevent further development of those (Bašić, 2009).

\footnotetext{
${ }^{1}$ Correspondence to:

Adela Jahić, Faculty of Education and Rehabilitation, University of Tuzla, Bosnia and Herzegovina

Univerzitetska 1, 75000 Tuzla, Bosnia and Herzegovina

E-mail: adela.jahic16@gmail.com
} 
Risk factors are related to unfavorable social conditions and circumstances which through their actions, by their presence and influence in the process of socialization, impede proper social development and prevent the formation of pro-social behaviors of children and young people, i.e. increase the likelihood of forming and exhibiting risky behaviors (Žižak, 2010). Risk is part of the psycho-dynamic transition process of maturation that entails the search for identity, and it often involves examining and shifting the boundaries of what is allowed. Risk can be the result of different types of deficits (social, material, family), just as it may be the result of the dominance of cultural values promoted by the materialistic culture of late capitalism. The question of the extent to which young people are at risk involves the discovery of a complex relationship in which power structures, reflexive individualization, determinism of social structure, and the capacity of young people to be adequately involved are intertwined (Sharland, 2005). There are three key risk factors that affect the social development and social behavior of children and young people: early and frequent antisocial behavior in school, school failure beginning in primary school, and insufficient commitment to school and school responsibilities (Hawkins, 2004). The emergence of risk factors in the school environment is significantly influenced by the system of social values, within which the status of educational activity in the system of social activity and social concern for school and school education is particularly important. Schools and even departments within the same school differ in terms of risk behaviors, levels of violence and victimization (Pavlovic \& Zunic-Pavlovic, 2012). These differences are explained by the so-called departmental/class norms pertaining to violence. However, it should be borne in mind that there are significant individual differences at departmental/class level. Thus, for example, individual children may have attitudes that may differ significantly from departmental/class norms (Velki \& Vrdoljak, 2012), but it should be borne in mind that both the individual characteristics and the family context of the child may influence his or her behavior in a particular situation (Bašić, 2009; Popovic-Citic, 2005; Popovic-Citic, 2007; Popovic-Citic \& Popovic, 2009).

Today, there are numerous programs in our area that deal with the continuum of interventions in the school environment, depending on the needs of the students. Selective and indicative prevention programs can be considered as intervention programs, since their purpose is to repair and change the current situation into the desired direction. An intervention is defined as a set of activities to which a group (or individuals) is exposed to change its behavior (Bašić, 2009). These interventions are preventative, because if successful, they prevent the occurrence of (new and more serious) behavioral problems (Zloković \& Vrcelj, 2010). Universal or early intervention programs are based on the development and strengthening of protective factors and are far more effective than programs that seek to reduce existing behavioral problems.

Early social-pedagogical intervention is classified on the continuum of prevention of behavioral disorders as a level of selective prevention preceded by universal prevention, supplemented by an indicated level of prevention (European Monitoring Centre for Drugs and Drug Addiction, 2009). In doing so, early socialpedagogical intervention involves an individualized approach to children and young people who already have severe behavioral problems at an early stage in their development. It is an intervention targeted at selected students who are involved in universal and early-intervention school curricula and activities, while students with intense behavioral problems require interventions and treatments that generally go beyond the capabilities of the school itself and imply an interdisciplinary and inter-departmental approach in the joint work of different services of the local communities. Early social-pedagogical intervention is a targeted professional and comprehensive, especially pedagogical, action in the school environment towards students who, for various reasons, are at risk of developing behavioral problems (Bouillet et al., 2015). Students with behavioral problems are significantly different, indicating the need for a comprehensive approach to detecting the difficulties and needs of these students in a timely manner, with the aim of providing them with appropriate support and interventions aimed at preventing more serious social and behavioral problems in the future.

Problems in the behavior of children and young people are an umbrella term for a continuum of behaviors from simpler, lesser significance, danger and harm to oneself and others, to those defined and / or sanctioned by regulations or often more severe by consequences and needs for intervention (KollerTrbović, Mirosavljević, \& Jeđud Borić, 2017). This term encompasses a continuum from risky behavior, through behavioral difficulties, to behavioral disorders (Koller-Trbović, Žižak, \& Jeđud Borić, 2011). In modern dimensional systems, the division into externalized and internalized behavioral problems is accepted (Achenbach \& Rescorla, 2001). 
Externalized syndromes refer to conflicts with other people and their expectations, which include behaviors that violate rules and aggressive behavior. The second group of problems includes types of selfdirected behavior, that is, internal problems such as anxiety, depression, somatic complaints without clear medical reasons, and social withdrawal.

\section{Aim of the research}

The aim of the research is to determine the prevalence of individual risk factors in relation to adolescents with externalized problems, adolescents with internalized problems and typically developed adolescents, and to determine in which segment, in the opinion of teachers, early social pedagogical intervention is most needed.

\section{METHODS}

The sample of respondents in this study consists of 450 students (233 male and 217 female) of the seventh and eighth grades of primary school. The research was carried out in the Municipality of Doboj Istok and Gračanica, in the primary schools of Klokotnica, Brijesnica, Lukavica and Hasan Kikić. The test was conducted with each respondent individually according to the test requirements. Emerging forms of risk behaviors were examined using the Achenbach Assessment System, the adolescent/youth self-report version (ASEBA Youth Self-Report - YSR, Achenbach $\&$ Resorla 2001). The instrument measures adaptive functioning, that is, competencies and maladaptive functioning, that is, behavioral, emotional, and social problems between the ages of 11 and 18 years. The instrument contains eight syndrome-specific scales that measure co-occurrence problems, such as: AnxietyDepression, Reticence-Depression, Somatic Problems, Social Problems, Thinking Problems, Attention Problems, Policy Violation Behavior and Aggressive Behavior. The syndromes are grouped as externalized and internalized. Statistical program SPSS 20.0 for Microsoft Windows was used for data processing.

\section{RESULTS AND DISCUSSION}

Table 1. Distribution of respondents by gender and age

\begin{tabular}{|c|c|c|c|c|c|}
\hline & & & $\begin{array}{c}\text { Seventh } \\
\text { grade }\end{array}$ & Eighth grade & \\
\hline \multirow[t]{6}{*}{ Gender } & male & Count & 93 & 140 & 233 \\
\hline & & $\%$ within gender & $39.9 \%$ & $60.1 \%$ & $100.0 \%$ \\
\hline & & $\%$ within grade & $47.9 \%$ & $54.7 \%$ & $51.8 \%$ \\
\hline & female & Count & 101 & 116 & 217 \\
\hline & & $\%$ within gender & $46.5 \%$ & $53.5 \%$ & $100.0 \%$ \\
\hline & & $\%$ within grade & $52.1 \%$ & $45.3 \%$ & $48.2 \%$ \\
\hline \multirow[t]{3}{*}{ Total } & & Count & 194 & 256 & 450 \\
\hline & & $\%$ within gender & $43.1 \%$ & $56.9 \%$ & $100.0 \%$ \\
\hline & & $\%$ within grade & $100.0 \%$ & $100.0 \%$ & $100.0 \%$ \\
\hline
\end{tabular}

Table 2. Discriminant values (lambda), group centroids (C), standard deviation (SD) of discriminant functions, F-test and level of statistical significance $(p)$

\begin{tabular}{cccccccccc}
\hline DF & Lambda & C1 & C2 & C3 & SD1 & SD2 & SD3 & F & $\boldsymbol{p}$ \\
\hline $\mathbf{1}$ & 1.0741 &,- 03 & .07 & -.09 & .38 & .32 & .38 & 3.30 & 0,37 \\
$\mathbf{2}$ & .0356 & .25 &,- 34 & .30 & 1.30 & .72 & 1.34 & .54 & .591 \\
\hline
\end{tabular}

Legend: C1- externalized behaviors; C2- internalized behaviors; C3-typically developed students

Discriminant analysis isolated two functions, but only one of which is a statistically significant discriminant function. 
Table 3. Structure of the discriminant function

\begin{tabular}{lcc}
\hline Variables & Discrimination coefficients & Discriminant functions \\
\hline Low risk & .52 & .67 \\
Medium risk & .67 & .93 \\
High risk & .29 & .14 \\
Very high risk & .03 & .78 \\
\hline
\end{tabular}

Of the two discriminant functions obtained, only the first one proved statistically significant. It is defined by a medium level of significance (.67), then low (.53), and somewhat by high (.31). Although the differences are significant at the $\mathrm{p}$ level of .05, however, the differences between the groups are very small, that is, the very low positive correlation with this discriminant function have students with externalized problems, in comparison with students with internalized problems. Given the position of the centroids, it is evident that the highest risk factors are present in the group of students with externalized behavior, slightly less in the group with internalized behavior, and the least in students without behavioral and emotional problems.

Table 4. Central tendency measures, measures of dispersion and asymmetries of the distribution of scores on the YSR scales

\begin{tabular}{|c|c|c|c|c|c|c|c|c|c|c|}
\hline \multirow[t]{2}{*}{ Variables } & \multirow{2}{*}{$\mathbf{N}$} & \multirow{2}{*}{ Min } & \multirow{2}{*}{$\operatorname{Max}$} & \multicolumn{2}{|c|}{ M } & \multirow[t]{2}{*}{ SD } & \multicolumn{2}{|c|}{ Skeewness } & \multicolumn{2}{|c|}{ Kurtosis } \\
\hline & & & & Stat & St.g & & Stat & St.g & Stat & St.g \\
\hline Anxiety/Depression & 450 & 15 & 40 & 23.14 & .19 & 4.33 & 1.07 & .10 & 1.71 & .20 \\
\hline Reticence/Depression & 450 & 7 & 19 & 11.71 & .10 & 2.41 & 1.16 & .10 & 1.37 & .20 \\
\hline Somatic Problems & 450 & 8 & 24 & 10.74 & .12 & 3.17 & 1.45 & .10 & 1.80 & .20 \\
\hline Social Problems & 450 & 10 & 25 & 13.07 & 13 & 2.75 & 1.39 & .10 & 2.70 & .20 \\
\hline Thinking Problems & 450 & 10 & 28 & 13.08 & .14 & 3.37 & 1.59 & .10 & 2.29 & .20 \\
\hline Attention Problems & 450 & 25 & 65 & 42.57 & .28 & 6.28 & .58 & .10 & .48 & .20 \\
\hline Violation & 450 & 12 & 28 & 16.21 & .12 & 2.91 & 1.41 & .10 & 2.28 & .20 \\
\hline \multicolumn{11}{|l|}{ Behavior } \\
\hline Aggressive Behavior & 450 & 20 & 53 & 29.16 & .24 & 5.34 & 1.18 & .10 & 1.58 & .20 \\
\hline Internalized problems & 450 & 33 & 86 & 46.69 & .37 & 8.37 & 1.20 & .10 & 2.00 & .20 \\
\hline \multirow[t]{2}{*}{ Externalized problems } & 450 & 32 & 79 & 45.37 & .32 & 7.62 & 1.54 & .10 & 2.01 & .20 \\
\hline & 450 & 172 & 447 & 251.74 & 2.01 & 46.55 & 12.5 & 1 & 18.2 & 2 \\
\hline
\end{tabular}

Analysis of the data in Table 4 shows that, on the sample Anxiety/Depression sub-scale, the students had achieved scores in the range of 15-40, with a mean of 23.14 ( $\mathrm{SD}=4.33)$. On the Reticence/Depression sub-scale, respondents achieved scores in the range of 7-19, with a mean of $(\mathrm{SD}=$ 2.41). Scores on the sub-scale Somatic Problems ranged from $8-21$, with a mean of $(\mathrm{SD}=3.17)$. In the Social Problems sub-scale, scores ranged from $10-25$, with a mean of $(S D=2.75)$. The Thinking Problems sub-scale has scores ranging from 10-28, with a mean of $(\mathrm{SD}=3.37)$. In the Sub-scale At- tention Problems, the score is ranged from 25-65, with a mean of $(\mathrm{SD}=6.28)$. In the Policy Violation Behavior sub-scale, the score ranged from 12-28, with a mean of $(\mathrm{SD}=2.91)$, while in the Aggressive Behavior sub-scale, the score ranged from 2053 , with a mean of $(\mathrm{SD}=5.34)$. At main Scales - Internalized and Externalized problems - scores varied from 33-86, with a mean of $(\mathrm{SD}=8.37)$ for Internalized problems and 32-79, with a mean of $(\mathrm{SD}=7.62)$ for Externalized problems, and the Total score ranged from 172-447, with a mean of (SD $=46.55)$. 
The school environment is considered as one of the most influential socialization domains in a child's life (Currie, Gabhainn, Godeau et al., 2008). The sense of school affiliation and academic achievement have proven themselves to be significant negative predictors of aggressive and risky gender behavior (Kyriacou, Mylonakou-Keke, \& Stephens, 2016).

Research has shown that experiences in school and adjustment to school can have both positive and negative impacts on development. Studying adolescents' interconnections, attachment, and engagement at school, Ert (2012) identifies three levels of successful school adaptation - individual level of school connection, friends connected to school (connection with schoolrelated peers), and avoidance of negative behaviors in school (e.g., cheating, skipping school, etc.). The importance of being attached to school friends with whom adolescents socialize indicates that a relationship with peers who have pro-social attitudes supports the pro-social behavior of the adolescents themselves. Hawkins (2004) points to a strong link between the children's poor adjustment to school and the use of drugs. A large number of aggressive children in the classroom increase the risk of developing behavioral disorders of other children. Risky behaviors may include impulsive decision-making, reckless behavior, quarreling with peers, or challenging authority, but they also include high-risk behaviors that have farreaching consequences on the life course of a young person. When it comes to school-based interventions by teachers, there are several obstacles they face. The main obstacle pointed out by teachers in assisting students is a lack of knowledge of social-pedagogical preventive interventions (Chart 1).

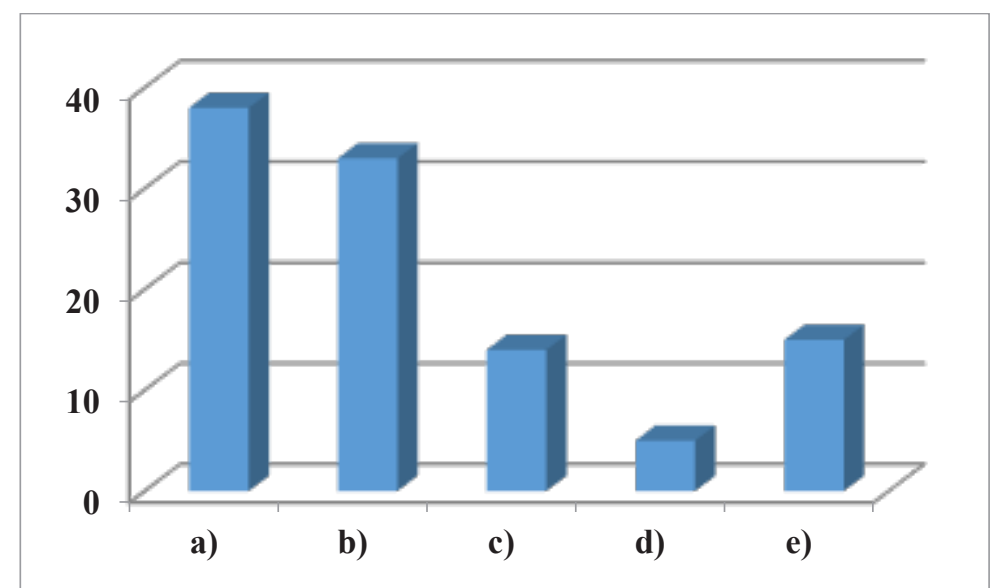

a) I do not know enough about methods of social pedagogical intervention

b) I'm running out of time

c) Insufficient cooperation with parents

d) Pupils refuse to be helped

e) I do not encounter obstacles, I successfully solve problems

Chart 1. Obstacles encountered by teachers when assisting students

Chart 2 presents a way of providing teacher assistance for stu- dents who have a behavioral problem.

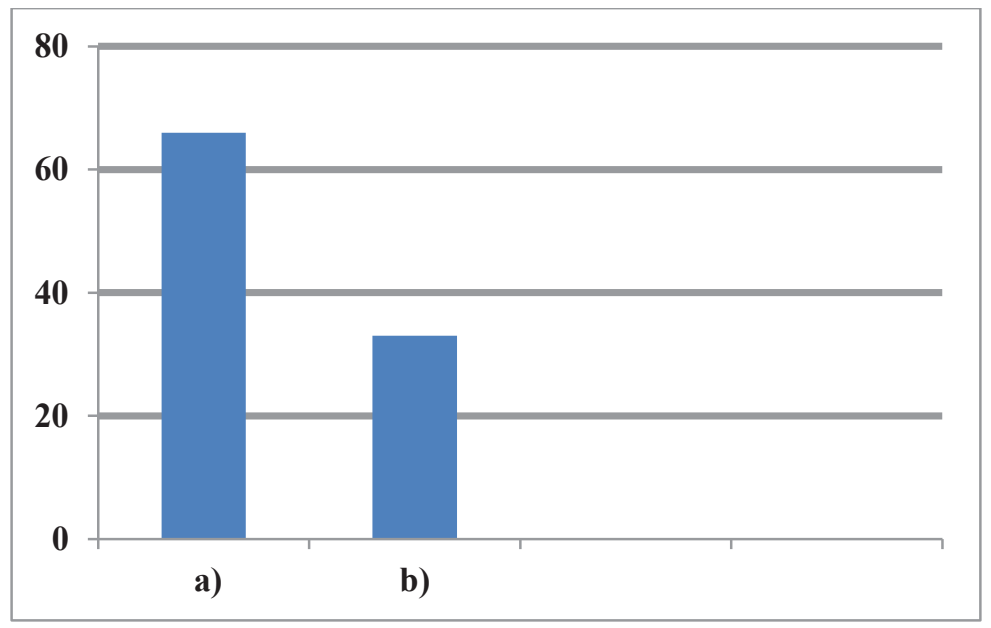

a) I talk privately with the student trying to cover up the cause of the behavior,

b) When I do not disclose the cause of the behavior in the interview, I inform the educator and the associate about the behavior.

Chart 2. Ways of teacher help to students with behavioral problems 
According to the analysis of the results of the research, it is found that teachers mainly use an individual approach to work in assisting students at risk for behavioral problems. The results of a qualitative study conducted by Koller-Trbovic and Zizak (2012) examining multiple perspectives on behavioral problems show that all interlocutors (teachers, school staff, local community representatives) understand children's and young people's behavioral problems as a complex social problem, they see its detrimental effect on society and its intensification in recent times. Through the different perspectives of the interlocutors, a common idea of the social conditionality of the phenomenon could also be observed. Teachers state that their main obstacle in providing adequate assistance to the adolescent with behavioral problems is their lack of knowledge of social-pedagogical methods. In schools, it is necessary for experts in the field of social-pedagogical interventions to be competent in this field. Research (Odak, Ristic Dedic, Bezinovic et al., 2010) confirms that successful schools have developed a special way of dealing with situations where a student has learning and / or behavioral problems, that they have an elaborate focused system of action to solve problems at the individual and group levels, that teachers give students with behavioral problems individual attention and that there is a consensus on values and good communication and collaboration among all individuals in the educational process. Contemporary concepts about young people who are woven into fears about the seriousness of disorders in the behavior of young people who over-incline to risky, even criminal, relate to their reality and problems of misunderstanding. At the same time, the risky behavior of young people is a cultural phenomenon that must be analyzed within the framework of cultural criminology, as an attempt to separate the real dimension of young people's relationships and the risks from their academic, and especially media dramatization. Despite the limitations of the human mind, adolescents have tremendous strength and potential for learning and development. Programs aimed at youth need to understand these potentials, the ways in which they are developed while respecting the profound complexity of teenagers' lives and the external post-modern world of disorder and insecurity (Larson, 2011). Regulating adolescent emotional being, boosting motivational capacity, and supporting self-regulation aims to turn anger and loneliness into collaboration and empathy, and the feeling of boredom and emptiness into work and life enthusiasm.

\section{CONCLUSION}

The whole spectrum of the process of socialization that takes place in a socially organized context is correlated with the individual characteristics of the developing person, and understanding the development process must take into account the change that changes both the individual and the social environment over time. The specific socio-economic, physical and emotional weaknesses of adolescents, while recognizing their own strengths and opportunities, may be the reason for the increased risk-taking tendency that emerges as a "transition challenge". The purpose of the research was to contribute to expanding the possibility of timely prevention and early intervention of problems in the behavior of students in the school environment in relation to the presence of risk factors. The results showed that the students expressed the need to implement programs aimed at prevention of risk factors present in the group of students with externalized behavior, slightly less in the group with internalized behavior, and at least in students without behavioral and emotional problems, and such programs are not usually sufficiently available in primary schools.

\section{REFERENCES}

Achenbach, T. M., \& Rescorla, L.A. (2001). The manual for the ASEBA school-age forms profiles. Burlington VT, University of Vermont: Research Center for Children, Youth, and Families.

Bašić, J. (2009). Teorije prevencije. Zagreb: Školska knjiga.

Bouillet, D. (2015). Konceptualni okvir razvoja modela rane odgojno-obrazovne intervencije. U:Bouillet D (ur.): Razvoj modela rane odgojno-obrazovne intervencije $u$ osnovnoj školi: od ideje do evaluacije. Zagreb: Forum za slobodu odgoja. 25-47.

Currie, C., Nic Gabhainn, S., Godeau, E., Roberts, C., Smith, R., Currie, D., \& Barnekow, V. (2008). Inequalities in young people's health: Health behavior in schoolaged children (HBSC). International report from the 2005/2006 survey. Copenhagen, Denmark: WHO Regional Office for Europe.

Eret, L. (2012). Odgoj i manipulacija: Razmatranje kroz razvojnu teoriju ekoloških sustava. Metodički ogledi 19(1) 143-161.

European Monitoring Centre for Drugs and Drug Addiction. (2009). Preventing Later Substance Use Disorders in At-risk Children and Adolescents: A Review of the Theory and Evidence Base of Indicated Prevention. Thematic papers. Luxembourg: Office for Official Publications of the European Communities.

Hawkins, J.D. (2004). Foreword; in: Allen-Mears, P., Fraser, M.W. (eds.) Intervention with Children and Adolescents: An Interdisciplinary Perspective. Boston, New York.

Kyriacou, Ch., Mylonakou-Keke, I., \& Stephens, P. (2016). Social pedagogy and bulling in schools: the views of university student sin England, Gereece and Norway. British Educational Research Journal, 42(4): 6311-645.

Koller-Trbović, N., Mirosavljević, A., \& Jeđud Borić, I. (2017). Procjena potreba djece $i$ mladih sa problemima $u$ ponašanju-konceptualne $i$ metodičke odrednice. Zagreb: Ured UNICEF-a za Hrvatsku.

Koller-Trbović, N., Žižak, A., \& Jeđud Borić, I. (2011). Standardi za terminologiju, definiciju, kriterije i način praćenja pojave poremećaja u ponašanju djece i mladih. Zagreb: Ministarstvo obitelji, branitelja i međugeneracijske solidarnosti i Povjerenstvo za prevenciju poremećaja u ponašanju djece i mladih Vlade Republike Hrvatske. 
Koller-Trbović, N., \& Žižak, A. (2012). Problemi u ponašanju djece i mladih i odgovori društva: višestruke perspective. Kriminologija $i$ socijalna integracija. 20 (1) $1-132$.

Larson, R.W. (2011). Positive development in a disorderly world. Journal of Research on Adolescence, 21, 317-334.

Odak, I., Ristić Dedić, Z., Bezinović, P., \& Rister, D. (2010). Kako škole vide sebe- Analiza samoevaluacijskog upitnika u projektu samovrednovanja škola. U: Bezinović, P. (ur). Samovrednovanje škola: Prva iskustva u osnovnim školama. Zagreb: Agencija za odgoj i obrazovanje $\mathrm{i}$ institute za društvena istraživanja u Zagrebu, 63-96.

Pavlović, M., \& Žunić-Pavlović, V. (2012). Koncept rezilijentnosti u savremenoj literaturi. Nastava $i$ vaspitanje, 2, 232-246.

Popović-Ćitić, B. (2005). Prevencija fokusirana na rizične i protektivne faktore kao savremeni pristup prevenciji prestupništva mladih. Socijalna misao, 12 (1), 27-55.

Popović-Ćitić, B. (2007). Porodični rizični faktori nasilnog ponašanja dece i omladine. Socijalna misao, 14(2), 27-50.
Popović-Ćitić, B. i Popović, V. (2009). Koncept rizičnih i protektivnih faktora - Klasifikacija i okviri za potrebe prevencije poremećaja ponašanja dece i omladine. Socijalna misao, 16(3), 43-65.

Velki, T., \& Vrdoljak, G. (2012). Uloga nekih vršnjačkih i školskih varijabli u predviđanju vršnjačkoga nasilnog ponašanja. Društvena istraživanja, 22 (1), 101-120.

Sharland, E. (2005). Young People, Risk Taking and Risk Making: Some Thoughts for Social Work. British Journal of Social Work, 36 (2). 247-265.

Sprague, J., \& Walker, H. (2000). Early Identification and Intervention for Youth with Antisocial and Violent Behavior. Council for exceptional children, 44, 355-371.

Zloković, J., \& Vrcelj, S. (2010). Rizična ponašanja djece i mladih. Odgojne znanosti, 12 (1), 197-213.

Žižak, A. (2010). Teorijske osnove intervencija. Zagreb: Edukacijsko-rehabilitacijski fakultet Sveučilišta u Zagrebu. 